\title{
発達した風波乱流場における界面波特性*
}

\author{
山本 義 暢*1, 功 刀 資 彰*2 \\ 佐 竹 信 一*3, 芹 澤 昭 示*2
}

\section{Numerical Investigation of the Water Surface-Waves Characteristics in Fully-Developed Wind-Driven Turbulent Flow}

\author{
Yoshinobu YAMAMOTO, Tomoaki KUNUGI*4, \\ Shin-ichi SATAKE and Akimi SERIZAWA \\ ${ }^{* 4}$ Department of Nuclear Engineering, Kyoto University, \\ Yoshida, Sakyo-ku, Kyoto-shi, Kyoto, 606-8501 Japan
}

\begin{abstract}
In this study, surfaces waves characteristics of fully-developed wind-driven turbulent flow, the maximum wind speed $2 \mathrm{~m} / \mathrm{s}$, were investigated used DNS data by means of MARS method for a coupled gas-liquid turbulent flow. As the results, large horizontal "scales" shaped wind-driven water surfaces consists of the low wave-number surface fluctuations, of which the spectra follow the -4 th power law. High wave number surface fluctuations were inactive in surface fluctuations or fluid velocity turbulent intensity behaviors near air-liquid interface. Dynamic processes compared with the coherent turbulent flow structures over fixed wavy wall, were observed, and were caused from the control factors with the phase difference, wind, surface waves and water velocity, in the air-liquid interface interation.
\end{abstract}

Key Words : Wind-Driven Water Surfaces, Air-Liquid Interface Interation, Turbulent Structures, DNS of Wind-Driven Turbulent Flow

1. 锟

気液界面上を高速の気流が流れ，界面における強い せん断力により界面変形を生じ, これにより生じる波 は一般に風波, これにより生じる水流は吹送流と乎ば れる. 風波の生成は気液界面におけるせん断力により, 表面張力を媒介として, 風から波へのエネルギー供給 により行われる，そして波は，風（乱流）と波自身ま た，その吹送流との相互作用により，徐々に発達ある いは減衰を絽り返すと考えられる，海洋においては, 風波の発達には，風の吹送距離，吹送時間あるいは， 風速が大きく関与していると考えられるが, 風自体が 非線形のランダムな乱流であり，その理論的な取り扱 いは困難で，ほとんどは統計的かつ半経験公式に基づ

* 原稿受付 2003 年 4 月 15 日.

*1 正員, サイクル機構日本学術振興会特別研究員 ( - 3 311-1393 茨城県東茨城郡大洗町成田 4002).

*2 正員, 京都大学大学院工学研究科( 8 606-8501 京都市左京 区吉田本町).

*3 正員, 東京理科大学基礎工学部( 3 278-8510 野田市山崎 2641).

E-mail : kunugi@nucleng.kyoto-u.ac.jp
いている(1). 実験室実験においては，近年，可視化と 計測技術を組み合わせた時空間測定が可能となりつつ あり(2,(3)，風波の発達過程及びその特性について興味 深い知見が得られているが，解像度・計測範囲さらに は速度場等との同時計測等に難点がある.

一方数值解析によるアプローチとして筆者らは, 功 刀による MARS 法(4)を基に, 複雑に変形する気液界面 を対象とした直接数值解析手法を確立し，風波乱流場 (気液混相乱流場)の直接数值計算を行い，その DNS 解 の妥当性を評価すると共に，風波とせん断乱流場との 相互作用及び気液界面を通しての乱流熱鍮送特性等に 関する考察を行ってきたの，(の，の，の．その結果，気液 界面を通しての乱流輸送過程においては，水平方向に 広がった鳞状の形をした大規模界面波と気相乱流との 直接的な相互作用が主因であり，風波乱流場の乱流構 造の形成において，界面波形状，大きさ等の影響が極 めて大きいこと等が示されている. そこで本研究にお いては, 気液間相互作用の重要な支配要因の一つであ る, 発達した風波乱流場に形成される界面波の基本特 性及びその波数依存性さらには，気相乱流場と相互作 用についてDNSデータベースを用いた解析を行う. 
Table 1 Numerical condition

\begin{tabular}{|c|c|c|c|c|c|c|c|c|}
\hline CASE & $R e_{\tau}$ & $\rho_{W} \rho_{g}$ & $W e$ & $\begin{array}{c}\text { Domain } \\
L x \times L y \times L z\end{array}$ & $\begin{array}{c}\text { Grid number } \\
N x \times N y \times N z\end{array}$ & $\begin{array}{c}\text { Resolution } \\
\Delta x^{+}, \Delta y^{+}, \Delta z^{+}\end{array}$ & $T_{0}^{+}$ & $T_{m}^{+}$ \\
\hline CASE1 & 150 & 842.1 & 2.78 & $10 h \times 2 h \times 5 h$ & $128 \times 164 \times 128$ & $11.72,0.264 .56,5.86$ & 4320 & 810 \\
\hline CASE2 & 150 & 842.1 & 2.78 & $10 h \times 2 h \times 5 h$ & $256 \times 164 \times 256$ & $5.86,0.26-4.56,2.93$ & 4210 & 800 \\
\hline
\end{tabular}

$R e_{\tau}=u_{\tau} h / v_{g}:$ Reynolds mumber, $u_{\tau}$ : Friction velocity at air-liquid interface in initial condition, $h$ : Gas Layer height, $v_{g}:$ Kinetic viscasity of air, $\rho_{w}$ : Water density, $\rho_{g}:$ Air density, We $e^{-\rho_{w}} u_{\tau} h / \sigma:$ Weber number, $\sigma:$ Coefficient of surface tension, $T_{0}{ }^{+}=T_{0} u_{\tau}{ }^{2} / v_{g}$ Computational time length from initial condition to fully-developed status, $T_{m}{ }^{+}$: Computational time length after fully-developed status

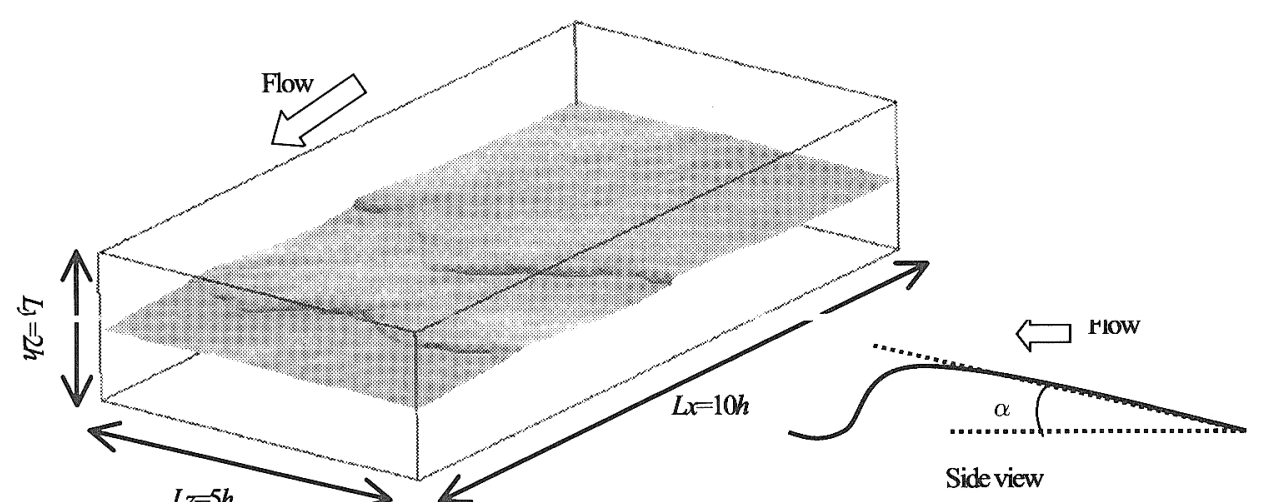

(1) Bind view

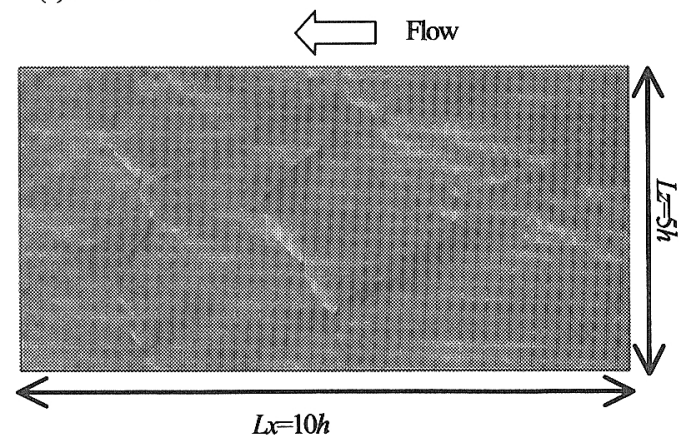

(3) Top view
(2) Surface gradient definition on $x-y$ plane

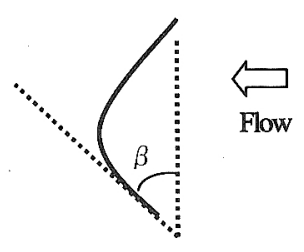

Top view

(4) Surface gradient definition on $x-z$ plane

Fig.1 Instantaneous wind-driven surface behavior

\begin{tabular}{|c|c|c|c|c|c|}
\hline \multicolumn{2}{|c|}{ Table2 } & \multicolumn{4}{|c|}{ Wind-driven waves properties } \\
\hline & & $\alpha$ & $\beta$ & $\eta_{\max }^{+}$ & Fr \\
\hline CASE2 & 3.5 & $\sim 4.2^{\circ}$ & $20^{\circ} \sim 58^{\circ}$ & 15 & 0.64 \\
\hline
\end{tabular}

\section{DNS データベースの概要}

本研究で対象とする流動場は，前報の（のにより得ら れた最大時間平均風速約 $2 \mathrm{~m} / \mathrm{s}$ の発達した風波乱流場
における DNS データベースである. 直接数值解析手 法の詳細に関しては, 文献(4)，(5)，(6)を参考にされ たい，境界条件は，主流及びスパン方向に周期境界条 件, 気相上面で freoslip 条件, 液相底面で no-slip 条件 とし，気相側に流量一定の条件を課している. 


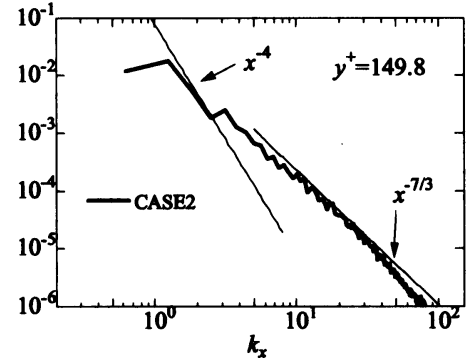

Fig2 1-D Energy spectra of VOF function, streamwise

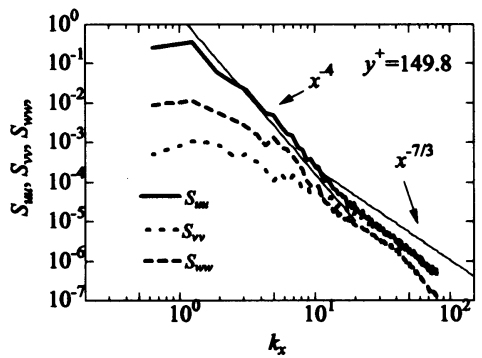

Fig3 1-D Energy spectra, streamwise, CASE2

次に計算条件を表 1 に示す. 座標系は主流方向を $x$ 軸，鉿直上向きに $y$ 軸，スパン方向に $z$ 軸とし，気相 高及び水深を $h$ とし, 各方向の計算領域はそれぞれ $L x=10 h, L y=2 h, L z=5 h$ である. また主流方向の平均流 速を $U$, 乱れ成分を $u$, 鉛直, スパン方向の乱れ成分 をそれぞれ $\boldsymbol{v}, \boldsymbol{w}$ としている． $\boldsymbol{R e}_{\tau}$ は初期条件におけ る気液界面における摩擦速度 $\left(\boldsymbol{u}_{\tau}\right)$ と気相高 $(h)$ 及び気相 における動粘性係数( $\left(\mathrm{g}_{\mathrm{g}}\right)$ に基づく乱流レイノルズ数, $\rho_{w} \quad \rho_{\mathbf{g}}$ は液相及び気相の密度, We は, 初期状態の 気液界面摩擦速度に基づくウェバ一数である．無次元 化は, 初期条件における気液界面における摩擦速度, 気相側の動粘性係数により行い，これらにより無次元 化された值を上付き添え字+で表記している。

\section{3. 解析結果}

3・1 界面波の基本特性 図 1 に CASE2 におけ る任意の瞬間における気液界面形態，界面波の概形， さらに $x-y$ 平面及び $x-z$ 平面上における界面勾配 $\alpha, \beta$ の定義を示す．また図 2 及び 3 に CASE2 における主 流方向への流体率（VOF 值）及び速度変動成分の工 ネルギースペクトル分布ののを示す．ここに $\boldsymbol{k}_{\boldsymbol{x}}$ は水深 $h$ で無次元化された主流方向の波数を示す.
鱗状の界面波は $x-y$ 平面においては，風下側に大き く傾いたクレストを有する波形分布をしており, 可視 化により見積もった界面勾配 $\alpha$ は $35^{\circ} \sim 42^{\circ}$, 一方 $x-z$ 平面における界面勾配 $\beta$ は $20^{\circ} \sim 58^{\circ}$ であり， $x-z$ 平面 における界面勾配 $\beta$ は比較的広篹囲の変動が見られる のに対し， $x-y$ 平面における界面勾配 $\alpha$ は，值及び変 動領域共に微小であった. 前報によりのの，発達した 風波乱流場においては，水平方向に大きく広がった鳞 状の界面波の大きさに相当する領域(図 2 の主流方向 波数で $k_{x} \doteqdot 1-3$, 物理空間では, $\left.l_{x}^{+} \doteqdot 130-290\right)$ において は, 主流方向エネルギースペクトル分布が-4 乗則に従 い，この界面波の影響が大きいのに対し，スパン方向 へは，低速・高速の縞構造を有する気相側における壁 乱流類似の乱流構造の影䇾を強く受けることが示され ているの（界面勾配 $\alpha$ より, 主流方向波長 $\lambda_{x}{ }^{+}=2$ $\eta_{\max }^{+} \tan \alpha, こ こ に \eta_{\max }{ }^{+}$は最大波高, と推定すると， $\lambda_{x}^{+}$は 200 程度となり, エネルギースペクトルが4 乗 則を示す空間領域と一致し，この鱗状の界面波が，発 達した風波乱流場における界面波構成の主因であるこ とがわかる．またこの鱗状の界面波が，単振動同様の 変動を示す比較的安定した波けであるめ, 鉛直断面 における界面勾配 $\alpha$ の変動値は, 微小になると考えら れる. 最後に, 界面波の基本特性值を表 2 に示す. 気 液界面近傍における液速度( 基づくフルード数 Fr $=u_{\text {mud }} d u_{\text {med }}$ は 0.64 程度であり，本 計算結果は吹送効果が卓越した風波乱流場であること が確認できる.

3・2 界面波の波数伎存性 本節においては, 上 記の鱗状の界面波における波数依存性さらにその乱流 統計量等への影翠を検討する. 解析手法としては，ま ず CASE2 で得られた任意の瞬間值図 1 の可視化と同 時刻)における，任意の物理量 $\boldsymbol{a}$ に対し以下のように 水平方向にフーリエ変換を行う.

$$
\begin{aligned}
& A(l, j, n)=\sum_{i=0}^{N x-1 N z-1} \sum_{k=0}^{N} a(i, j, k) \times \\
& \quad \exp \left\{-2 \pi r\left(\frac{l i}{N x}+\frac{n k}{N z}\right)\right\} \frac{1}{N x N z}, I=\sqrt{-1},(1) \\
& l=-N x / 2, \cdots, N x / 2-1, n=-N z / 2, \cdots, N z / 2-1
\end{aligned}
$$

この時, 図 4 中における主流方向の波数 k及びスパン方 向波数には以下のように表せる.

$$
k_{x}(l)=2 \pi \frac{h}{L x}, k_{z}(k)=2 \pi k \frac{h}{L z} \text {. }
$$


Table 3 Analysis condition

\begin{tabular}{|c|c|c|c|}
\hline CASE & $\begin{array}{c}\text { Gridnmber } \\
M b x, M_{z}\end{array}$ & $\begin{array}{c}\text { Resohtion } \\
\Delta x^{+}, \Delta z^{+}\end{array}$ & $\begin{array}{c}\text { Wavenumber } \\
k_{\text {mon }} k_{\text {max }}\end{array}$ \\
\hline CASE2 & 256,256 & $5.86,293$ & $\mathbf{7 9 . 8 0 , 1 5 9 . 5 9}$ \\
\hline CASE1 & 128,128 & $11.72,5.86$ & $39.58,79.17$ \\
\hline (a) & 128,128 & $11.72,5.86$ & $39.58,79.17$ \\
\hline (b) & 64,96 & $23.44,7.81$ & $19.48,59.06$ \\
\hline (c) & 32,96 & $46.88,7.81$ & $9.42,59.06$ \\
\hline (d) & 16,96 & $93.75,7.81$ & $4.40,59.06$ \\
\hline (e) & 16,16 & $93.75,46.88$ & $4.40,8.80$ \\
\hline
\end{tabular}

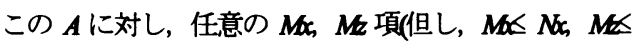
NG)について, 以下のフーリエ逆変換を行い，高波数成 分を除去した物理量 $b$ を算出する.

$$
\begin{aligned}
b(i, j, k)= & \sum_{l=-M x / 2}^{M x / 2-1} \sum_{k=-M z / 2}^{M z / 2-1} A(l, j, n) \times \\
& \exp \left\{2 \pi I\left(\frac{l i}{M x}+\frac{n k}{M z}\right)\right\}, I=\sqrt{-1},
\end{aligned}
$$

$i=0, \cdots, M x-1, M x \leq N x, k=0, \cdots, M z-1, M z \leq N z$

この作業を速度場, VOF值等に施し, 界面波における波 数依存性及びその乱流統計量への影鄰を評価する. 主流 方向への有効モード数 Mxは，最大項数 256 から 12 づつ 小さくした，128，64，32，16 とする. 同様に MEに関し ては, 1/2ぶつ小さくとるが, スパン方向の特性量は気 相側のせん断乱流場であるのての，この乱流通動を再 現できる 2 次精度中心差分における最小の格子解像度 四として $\Delta z^{+}=75$ 程度は必要と考え, 96 モード $\left(\Delta z^{+}=78\right)$ を 下回る場合は96に固定した. 但し, 最小の16モードの 場合のみ、スパン方向モード数も等しく 16 とした条件 を計算している. この解析の計算条件を表 3に示す.こ れらのケースは, ケース(a)が CASE1 と同様の解像度, ケース(b)が主流方向の界面近傍速度場成分におけるエネ ルギースペクトル分布が4 乗則を示す領域。ケース(dが， 主流方向の界面変功エネルキースペクトルが4 乗則に従 う領域までを，それぞれ解像できるケースとなっている。 図 4に各ケースにおける気液界面の形状を示す. 最も解 像度が低いケース(あ)においても，鳞状の水面波の概形は 確認できる. また, 時間的相関がないので定量的な比較 は難しいが，CASEl と解像度が等しいケース(a)は，図 4 (のに示した CASE1 の気液界面形状と比較すると，鳞状 の水面波の上に現れる教状の界面変動がより多く現れて いる. そして, CASEl の界面形䈍は主流方向に 32 モ一 ド用いたケース(c)程度の界面変形しか解析できていない ように思われる. これは, 差分法の解析においては，解 像度が異なると，同波数における有效波数の分布が変化 する等の効果も一因と考えられる. しかし，界面波の計
算において重要な役割を果たすのは，表面張力とこれに 釣り合う圧分布である. 表面張力は界面曲率により算 出され，また単相乱流の直接数值計算においても解像度 の変化により比㜞的その影鄰を受けやすい低次の統計量 は圧力であるため(1)，界面曲率の精度と圧力分布の違い が, 解像度が低い CASE1 において，大規模な撛状の界 面波上のより細かい秛状の界面変動を解像できない原因 と思われる. 但し, CASE1 及び CASE2における圧力変 動の乱流統計量分布? は, よく一致しており，CASE1 においても気液間相互作用を解析する DNS データベー スとして十分有用であることは確拝されている.

図 5 に次式(4)で定義される圧力のラプラシアンの気液 界面近傍における分布を示す. 界面が存在しない場所に おいては, この值が正の領域は速度勾配テンソルの第 2 不変量に相当し, 局所的な瀜運動が散冕を上回る領域に 相当する. しかし，界面近傍においては，渦運動と表面 張力効果を合わせたものとして表現され，気液界面近傍 においては，表面張力効果の強い領域が主に可視化され ていると考えられる.

$$
Q=\frac{\partial}{\partial x_{i}}\left(\frac{1}{\langle\rho\rangle} \frac{\partial p}{\partial x_{i}}\right)
$$

図 5 において CASE1 及び CASE2を比較すると, CASE1 は大規模な觶状の界面波のクレスト部分は同様に検出さ れているが, 界面波上の細か、界面変動はほとん ど検出されておらず, 図 4 の界面形態分布の結果と一致 する.

図 6 に CASE2，主流方向有効モード数が 32 のケース (c)及び解像度の最も低いケース(e)における空間平均によ り算出した界面変動の乱流強度の分布を示す. CASE2 と ケース(c)を比較すると, ケース(c)においては, ほぼ CASE2の界面変動分布が再見できることがわかる. また 鱗状の界面波以外ほとんど解像されていないケース(e)に おいても，CASE2 と比較的よく一致しており，大規模な 鳞状の界面波上の細か心状界面変動は界面変動の工 ネルギー強度にほとんど奇与しないことがわかる.

図 7に同様に空間平均により算出した CASE2，ケース (c)，(d)（e)の速度に関する乱流強度分布を示す. 界面近 傍領域以外における速度場の乱流統計量の分布において は, 解像度が低いほど非等方化が顕著になり, 単相乱流 のDNSにおける解像度の変化に対する精度の変化四と同 様の傾向が現れている. しかし界面変動領域においては, 解像度が極めて粗いケース(e)と CASE2においてもその 分布形に差異はほとんど見られない．

図8に図 1 と同時刻における CASE2 の界面形状と主流 方向変動速度分布を示す. 図 8(1)においては, 鱗状の形 
Flow

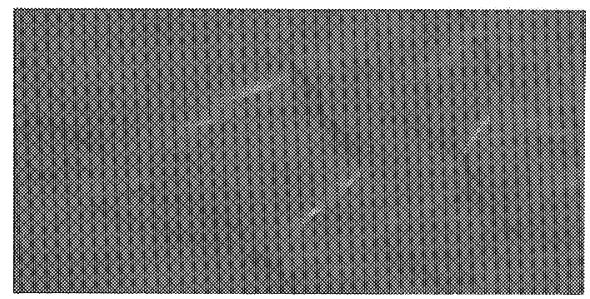

(1) (a) $128 \times 164 \times 128$

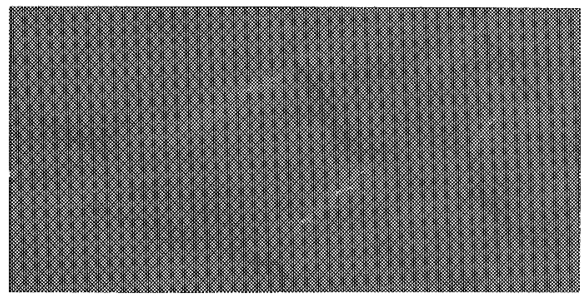

(3) (c) $32 \times 164 \times 96$

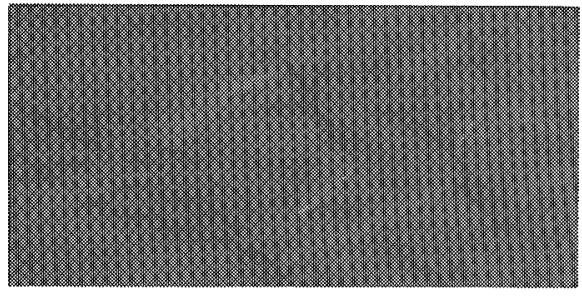

(5) CASE2 $256 \times 164 \times 256$

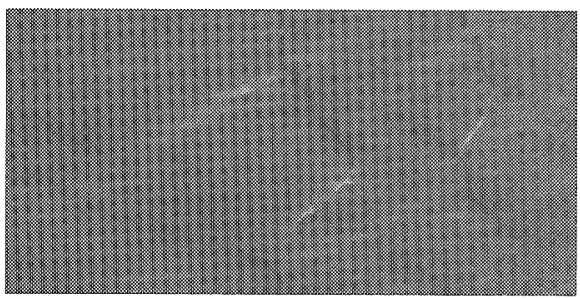

(2) (b) $64 \times 164 \times 96$

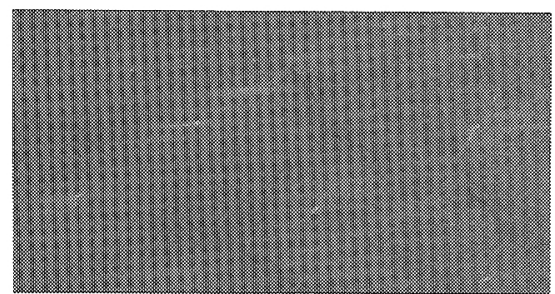

(4) (d) $16 \times 164 \times 96$

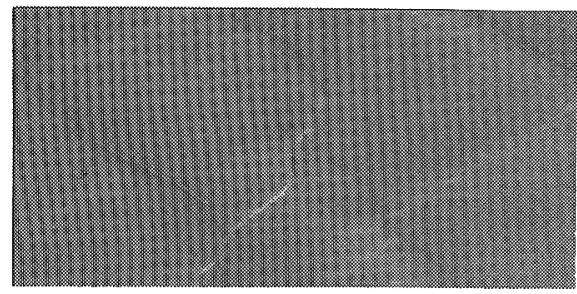

(6) CASE1 $128 \times 164 \times 128$

Fig.4 Water surface behaviors in several effective modes

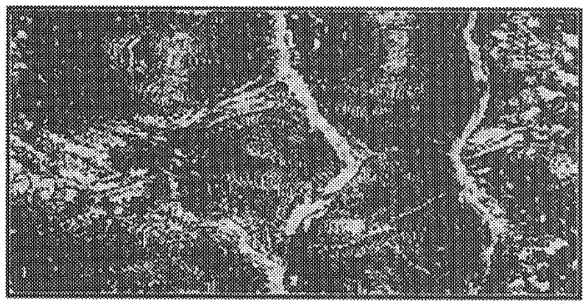

(1) CASE2 $256 \times 164 \times 256$

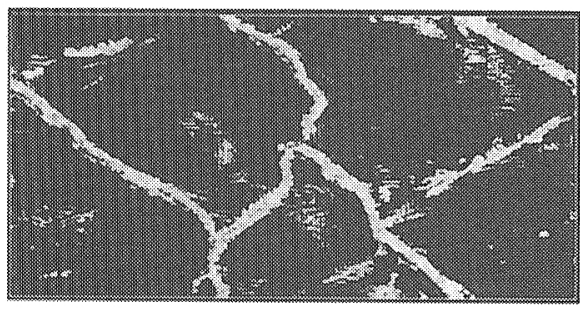

(2) CASE1 $128 \times 164 \times 128$

Fig.5 Distributions of the pressure Laplacian, $Q^{+}=0.03$

をした界面波の両端部分に，気相側の高速ストリーク (図 8(1)中における点線円中コンターの白色部分)に誘起 された新たな界面波が形成されつつある様子が伺える. また図 8(2)においては，界面波の風上側に界面波を誘起 する気相の高速ストリークの存在と界面波のクレストの
風下側に低速流体とその巻き上がり(図 8(2)における点 線円中コンターの黒色部分)が確認できる. このように 気液間相互作用においては，従来指摘されていたような 固定波状路類似の加速・減速を伴亏圧力勾配流九や界面 波のクレストからの剥離円と言う構造よりもむしろ, 高 


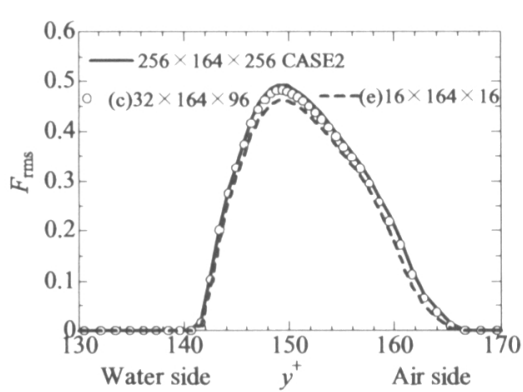

Fig6 R.M.S. of VOF function distributions, near interface

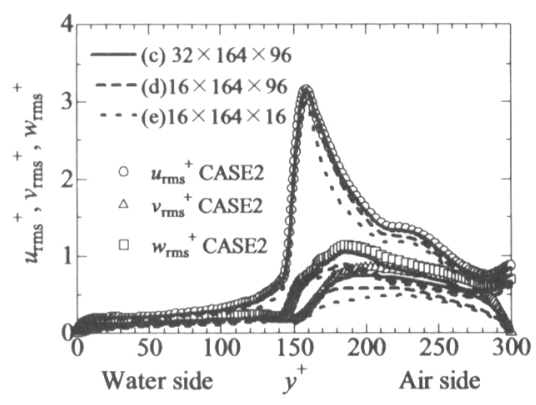

Fig.7 Turbulent intensity profiles

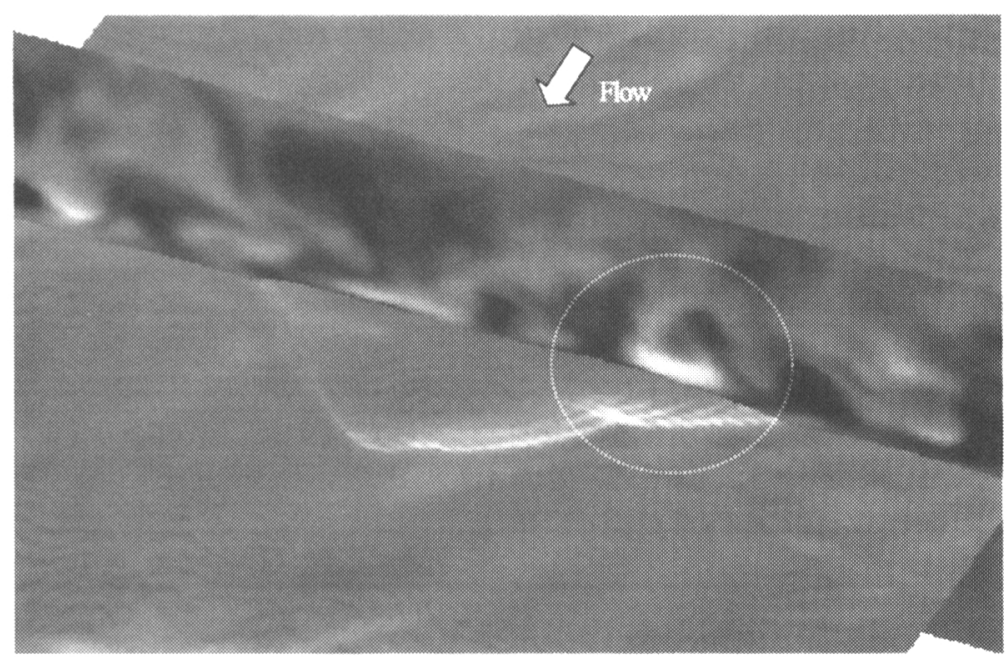

(1) Generation of wind-driven surface waves, $-0.25[\mathrm{~m} / \mathrm{s}](\mathrm{black})<u 40.65[\mathrm{~m} / \mathrm{s}]($ White), CASE2

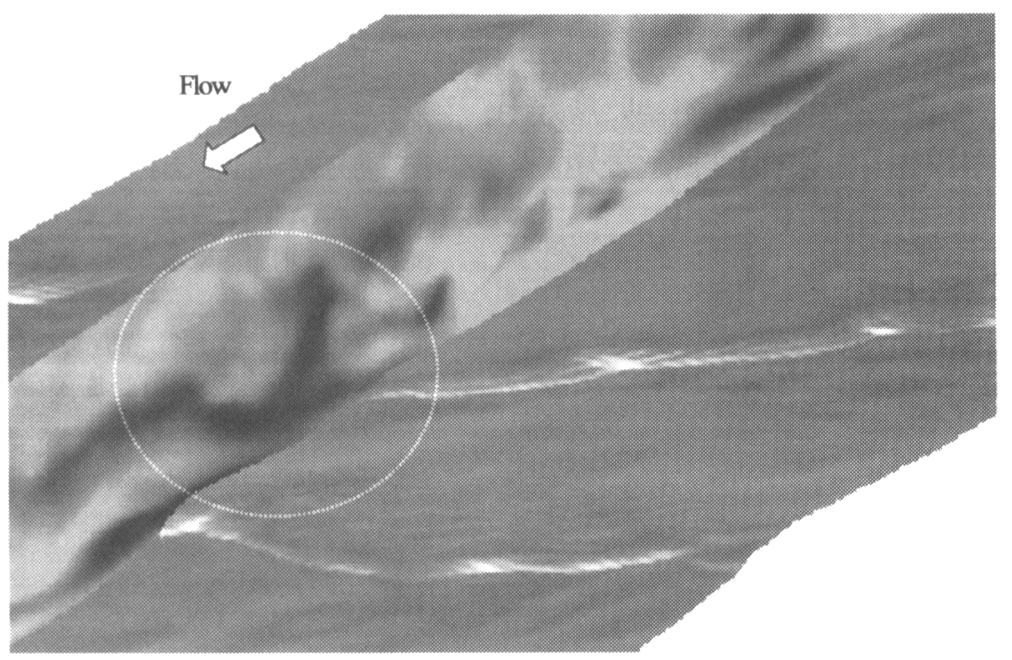

(2) Lifted up the low velocity components by the wind-driven surface waves, $-0.45[\mathrm{~m} / \mathrm{s} /$ (black) $<u<0.05[\mathrm{~m} / \mathrm{s} /$ (White), CASE2

Fig.8 Interaction between wind-driven water surfaces and the turbulent shear gas flow 
速ストリークにより界面波の誘起, それに伴う界面波に よる低速流体のかき集め及び界面波クレスト近傍での Miro scale breaking のあるいは低速流体の巻き上がりと言 ったより動的な組織構造か確忍できる.これは，気液界 面近傍の乱流構造は，気相乱流・界面波・吹相流力密接 に相互作用しながら形成されるのものの, 物性值等 の違いに基づく各相独自の乱流構造が形成されるための， 各フエイズの移動速度も同一ではなく, このため固定波 状路流れ類似の乱流構造に加えてよりダイナミックな気 液間相互作用の構造力存在するものと考えられる. また 上述の組織構造, 界面波の基本特性及ひ波数依存性の解 析結果は, 風波乱流場における空間支配スケール及び気 液界面近傍の二相流的な乱流構造を解析した前鉱の ®の結果から推察された界面波の特性とよく整合してい る.

以上より，界面近傍においては，状状水面波と，平 均流あるいはせん断乱流場を構成する維渭構造に相当す る比較的大規模の乱流場による相互作用による影䍌力支 配的であり, それ以下の乱流変動及ひ界面変動効果は, 気液間相互作用を支配する界面近傍における力学過程に 寄与せず, 界面変動, 速度場の統計量の分布形に直接的 な影響を与えないことがわかり, 気液界面を通してのス カラー輸送における高波数界面变動の効果が比的不活 性穴なる原因の一つ考えられる。

\section{4. 结}

本研究においては，気液混相乱流場に対する直接数值 解析手法である MARS 法による DNS テータベースに基 づき, 最大風速 $2 \mathrm{~ms}$ の発達した風波乱流場に形成され る界面波の特性及びその気液間相互作用への影篅につい て考察を行い，以下の知見を得た.

1. 発達した風波乱流場に形成される水平方向に 大きく広がった镂状の界面波の波形勾配は鉆 直平面においては, 小さく, 安定であるが, 水平方向については，比較的大きくかつ変動 幅も大きい.

2.この界面波は, 気相乱流の空間スケールで 130-290 程度の低波数成分により構成され，こ れ以下の界面変動は，界面変動及び界面近傍
の速度場における乱流強度分布の構成にほと んど奇与しない.

3. またこの界面波の基本特性は，風波乱流場に おける気液界面近傍の乱流構造及びその空間 支配スケールの解析結果@のと良く整合 する.

4. 風波乱流場における気液間相互作用において は，気相乱流場における高速ストリークによ り界面波の誘起，それに伴う界面波による低 速流体のかき集め及びその巻き上がりと言つ た動的な組織構造力存在する.これは，気液 界面近傍の乱流構造は，気相乱流・界面波・ 吹相流が密接に相互作用しながら形成される ものの, 各フェイズの険送速度の量いに伴う ずれが生じていることに起因すると考えられ る.

本解析の一部は, 理化学研究所のスーパーコンピュ ーターシステム VPP700E を利用して行われた. 本研 究の一部は特別研究員采励费(No. 200103393)の援助を 受けて行われた. 記して碀意を表する.

\section{文嗝}

(1) Kawai, S.J. Fuid. Mech, 93,(1979), pp.661-703.

(2) Siddiqui, M.HK, a al, Physics of Fluids, 13 (7) (2001), pp.1891-1903.

(3) Veron, F. and Melville, W.K., J. Fluid Mech, 446, (2001), $\mathrm{pp} .25-65$.

(4) 功刀, 機論 B編，63-609(1997)pp.1576-1584.

(5) 山本ら, 機論 B編, 68-665(2002)pp.63-71.

(6) 山本ら, 機論 B編, 69-687(2003)pp.2479-2485.

(7) 功刀5, 九大応力研研究集会報告, $14 \mathrm{ME}$ (2003)

(8) 山本ら，機論 B縞， No.03-0269(揭载决定)

（9）鈴木 - 河村，機論 B編，60-578(1994)pp.3280-3286.

(10) 永翁，機論 B縞，65-632(1999)pp.1318-1325.

(11) 阿部ら，機諞 B 編，66-647(2000)pp.1698-1704.

(12) 棍島, 乱流の数値シミュレーション, 養畫堂 (1999)

(13) Komori, S., et al, J. Fluid Mech, (1993) pp.161-183. 